\title{
Integration of potassium fertilizer with mechanically prepared potassium- enriched compost from city market waste for improvement in maize production
}

\author{
Ahmed Naqi Shah ${ }^{1 *}$, Muhammad Nawaz Kandhro ${ }^{1}$, Qamarddin Jogi ${ }^{1}$, \\ Zia-UL-Hassan Shah ${ }^{2}$ and Ghulam Murtaza Jamro ${ }^{2}$ \\ 1. Department of Agronomy, Sindh Agriculture University Tandojam-Pakistan \\ 2. Department of Soil Science, Sindh Agriculture University Tandojam-Pakistan \\ *Corresponding author's email: ahmednaqishah@gmail.com \\ Citation \\ Ahmed Naqi Shah, Muhammad Nawaz Kandhro, Qamarddin Jogi, Zia-UL-Hassan Shah and Ghulam Murtaza \\ Jamro. Integration of potassium fertilizer with mechanically prepared potassium-enriched compost from city \\ market waste for improvement in maize production. Pure and Applied Biology. Vol. 8, Issue 1, pp847-855. \\ http://dx.doi.org/10.19045/bspab.2019.80026
}

\begin{tabular}{llll}
\hline \hline Received: 20/12/2018 & Revised: 19/02/2019 & Accepted: 15/02/2019 & Online First: 12/03/2019 \\
\hline \hline
\end{tabular}

\section{Abstract}

In modern agriculture, potassium $(\mathrm{K})$ is being considered as an indispensable nutrient for sustainable crop production. However its use is negligible or minimal in current agricultural practices of Pakistan. In view of the significance of $\mathrm{K}$, a field experiment was conducted to evaluate the effects of $\mathrm{K}$ enriched recycled organic wastes (potassium enriched compost- KEC) for improving yield of hybrid maize (Hycorn-11-plus). The KEC was prepared from the market wastes (fruits and vegetables) using mechanical composter at Institute of Soil and Environmental Sciences, University of Agriculture, Faisalabad, Punjab, and applied @ $300 \mathrm{~kg} \mathrm{ha}^{-1}$. The inorganic $\mathrm{K}$ treatments were involved 0, 60, 45, $30,15 \mathrm{~K}_{2} \mathrm{O} \mathrm{ha}^{-1}$ in the form of potassium sulphate $\left(\mathrm{K}_{2} \mathrm{SO}_{4}\right)$. The randomized complete block design was used. The enrichment of compost with $\mathrm{K}$ reduced carbon to nutrient $(\mathrm{N}, \mathrm{P}, \mathrm{K})$ ratios and improved the nutrients content of the compost. The results of field study revealed that integration of KEC and inorganic $\mathrm{K}$ fertilizer $\left(\mathrm{K}_{2} \mathrm{SO}_{4}\right)$ showed that growth and yield traits of maize (including $\mathrm{K}$ concentration of maize stover and grain) improved under the combined application of 60 and or $45 \mathrm{~kg}$ $\mathrm{K} \mathrm{ha}^{-1}$ in conjunction with $300 \mathrm{~kg} \mathrm{KEC}$ improved most of the as against $60 \mathrm{~kg} \mathrm{ha}^{-1} \mathrm{~K}$ alone. The overall findings of present study suggested that the use of KEC @ $300 \mathrm{~kg}$ with 75\% inorganic K fertilizer (45 $\left.\mathrm{kg} \mathrm{K} \mathrm{ha}^{-1}\right)$ improved growth, yield and $\mathrm{K}$ concentrations of hybrid maize.

Keyword: Compost; Maize production; Market waste; Potassium

\section{Introduction}

Potassium $(\mathrm{K})$ is a key element for the enhancing the vigour and it makes plant healthy because it plays the active role in many plant physiological functions [1]. The use of potassium has increased quickly due to all around globe required for K nutrient 32802 (000) in 2016 might be increased up to 35257 (000) by 2019 [2,
3]. The potash nutrient is costly as compared to other essential elements and it is very difficult to purchase by farmers in our country as well worldwide [4]. The large areas of Pakistani soils are suffering to deficiency of potassium that can be destroyed of Agriculture production [5]. The shortage of potassium in Pakistan 20 $\mathrm{kg}$ per hectare in the 1985 year then 
maximum $26 \mathrm{~kg}$ per hectare in the year 1995. The potassium fertilizer usage is very low $0.3 \mathrm{~kg} \mathrm{ha}^{-1}$ as the compare to 0.8 $\mathrm{kg} \mathrm{ha}{ }^{-1}$ in worldwide agriculture [6]. Moreover failing of potassium in Pakistani, soil have been much more in the last ten years that is vital in our country [7]. Maize (Zea mays L.) is a commonly grown grain crop in world and has significant important in Pakistan due to increasing in population rate and diminishing soil resources at an alarming rate. In Pakistan, maize crop occupied $3^{\text {rd }}$ place after wheat and rice cereal crops. The maize was grown on an area of 1,144 thousand hectares with an average yield of 4,301 kg ha-1 during 2015-16.

While the average in Pakistan grain and yield of maize is very low as compared to other world countries. In this regards, potassium nutrient is considered more rapidly enhance the growth and development of maize [8]. Maize is also more potassium $6.9 \mathrm{~kg}$ ha- 1 per day uptake when maize produced 12 tones biomass per hectare [9], as well as potassium is primary nutrient which can be promoted growth and quality of maize [10]. The maize plants are might be efficiently uptake five $\mathrm{kg}$ ha-1 potassium per day during the early growth of maize crop. The greater potassium accumulated varieties which possess more potential to uptake potash [11]. So therefore, without the optimum quantity of potassium cannot be obtained better growth, yield and quality parameters of maize crop [12]. The organic substance involved and improver of soil physical, chemical and biological activities and their properties [13, 14]. In Pakistan, the bulk of city waste such as industrial, market and mill wastes has been using for agriculture. These wastes can be applied in raw or unrecompensed form for plant growth and development [15, 16]. Composting is the technique of decomposition of waste material such as crop residual and industrial waste [17], due to the preparation of compost with inorganic fertilizers can decrease inorganic matter levels [18]. The analyze were performed to examine, the advantages of potassium, enriched organic fertilizer (KEC), made organically from wastes, mixed with inorganic $\mathrm{K}$ fertilizer for the production of maize and sustainability.

\section{Materials and methods \\ Preparation of potassium enriched compost}

Market waste (fruit and vegetable organic wastes) was collected. The Mechanical Composting Unit was used to process organic waste material at UAF, Faisalabad, Pakistan. It comprised of a crusher/ grinder, a fermenter, a granulator and a drying cabin [19]. The material air dried, sorted and ground, followed by material was placed in oven at $70^{\circ} \mathrm{C}$ for 2-days for complete dried for advancing surface area, material was crushed ( $<2 \mathrm{~mm}$ size particle size) and the fermented in compost having vessel of 0.5 ton for developing well decomposed compost material. An amount of $40 \mathrm{~L}$ water $/ 100 \mathrm{~kg}$ organic material was added to achieve $40 \%$ moisture during composting process. For providing aeration for decomposing process the oxygen inlet was made available. The aeration was maintained through oxygen inlet. The temperature was maintained between $30-70^{\circ} \mathrm{C}$ during the process of composting which completed in 5 days. The $10 \%$ of recommended inorganic $\mathrm{K}$ was mixed for preparing KEC

\section{Experimental design and treatments}

The experiment involved six treatments including control (No-K), $300 \mathrm{~kg} \mathrm{KEC} \mathrm{ha}$ ${ }^{1}, 60,45,30,15(\mathrm{~kg} \mathrm{~K})+300 \mathrm{~kg} \mathrm{KEC} \mathrm{ha}{ }^{-1}$ and replicated four times in randomized complete block design (RCBD). The plot size of each experimental unit was kept $5 \mathrm{~m}$ $\mathrm{x} 6 \mathrm{~m}=30 \mathrm{~m}^{2}$. The land was properly prepared before planting maize. The hybrid maize (Hycorn-11-plus, ICI, Pakistan Limited) was used as test crop. The seed was soaked before sowing and seed was applied at the rate $60 \mathrm{~kg} \mathrm{ha}^{-1}$ through drilling method. The required irrigations were applied according to recommendations provided by concerned 
Agriculture Department, Government of Sindh. The practices of agronomy were carried out during full life cycle of the maize crop. The recommended rates of $\mathrm{N}$ and $\mathrm{P}$ were applied. The $\mathrm{N}$ was applied @ $150 \mathrm{~kg} \mathrm{~N} \mathrm{ha}^{-1}$ in urea (N:46\%), whereas $\mathrm{P}$ was applied @ $75 \mathrm{~kg} \mathrm{P}_{2} \mathrm{O}_{5} \mathrm{ha}^{-1}$ in diammonium phosphate, DAP $\left(\mathrm{P}_{2} \mathrm{O}_{5}: 46 \%\right.$, $\mathrm{N}: 18 \%$ ). The SOP (sulphate of potash) was supplied as source of $\mathrm{K}$ chemical fertilizer. At the time of sowing, all $\mathrm{P}$ and $\mathrm{K}$ (according to treatment plans of various studies) and $50 \%$ of recommended $\mathrm{N}$ fertilizers were broadcasted. The remaining $50 \%$ of $\mathrm{N}$ dose was applied at the time of first irrigation. The dose of $\mathrm{K}$ enriched organic fertilizer@300 kg ha ${ }^{-1}$ was applied for each plot.

\section{Compost material properties \\ Soil analysis}

Physical and chemical properties (1) texture (2) Electrical Conductivity (EC) (3) Soil pH (4) OM (5) K element these all parameters were analyzed methods followed by [20].

\section{Agronomic observations}

Randomly five samples were chosen with completed maturity from each treatment then averaged, plant height $\mathrm{cm}$, member of cobs plant ${ }^{-1} 1000$ grain weight g, grain yield $\mathrm{kg} \mathrm{ha}^{-1}$ and stover yield $\mathrm{kg} \mathrm{ha}^{-1}$.

\section{$K$ concentration in grain and stover}

The total $\mathrm{K}$ content (\%) in maize grain and harvest index were determined as described by [21].

Statistical analysis

Table 1. Compost material properties

\begin{tabular}{|c|c|c|}
\hline Name of property & $\begin{array}{c}\text { Before potassium } \\
\text { enriched composting }\end{array}$ & $\begin{array}{l}\text { After potassium enriched } \\
\text { composting }\end{array}$ \\
\hline $\mathrm{C}$ to $\mathrm{N}$ ratio & 27.6 & 13.9 \\
\hline C to P ratio & 78.2 & 34.6 \\
\hline $\mathrm{C}$ to $\mathrm{K}$ ratio & 27.0 & 10.8 \\
\hline N Concentration $\left(\mathrm{g} \mathrm{kg}^{-1}\right)$ & 11.8 & 15.3 \\
\hline P Concentration $\left(\mathrm{g} \mathrm{kg}^{-1}\right)$ & 4.2 & 6.2 \\
\hline K Concentration $\left(\mathrm{g} \mathrm{kg}^{-1}\right)$ & 12.0 & 19.5 \\
\hline Cu Concentration $\left(\mathrm{mg} \mathrm{kg}^{-1}\right)$ & 1.1 & 14.0 \\
\hline Fe Concentration $\left(\mathrm{mg} \mathrm{kg}^{-1}\right)$ & 485.0 & 630.0 \\
\hline Mn Concentration (mg kg-1) & 38.7 & 54.0 \\
\hline Zn Concentration $\left(\mathrm{mg} \mathrm{kg}^{-1}\right)$ & 39.5 & 49.8 \\
\hline
\end{tabular}

The collected data was tested for examine different (ANOVA) technique by using computer software Statistix ver.8.1 [22]. The honestly significant difference (HSD) test applied for mean separations at alpha 0.05 , where $\mathrm{P}$ value was significant.

\section{Results}

\section{Compost material properties}

In raw organic material the $\mathrm{C}$ : $\mathrm{N}$ ratio noted was 27.6 which under conducted the composting conditions after 5 days of compost process limited to 13.9. Similarly, organic material showed 78.2 and 27.0 ratio of $\mathrm{C}$ : $\mathrm{P}$ and $\mathrm{C}$ : $\mathrm{K}$, and after composting decreased to 34.6 and 10.8 , respectively table 1 . The process of composting improved nutrient percent of organic material. It illustrated 11.8, 4.2 and $12 \mathrm{~g} \mathrm{~kg}^{-1}$ content of NPK in raw of waste materials in respectively. The respective $\mathrm{N}, \mathrm{P}$ and $\mathrm{K}$ contents of organic waste material after composting enhanced to $15.3,6.2$ and $19.5 \mathrm{~g} \mathrm{~kg}^{-1}$. In the same way zinc, iron, manganese and copper and content of raw organic waste materials was $39.5,485.0,38.7$ and $1.1, \mathrm{mg} \mathrm{kg}^{-1}$ which after composting process and increase the 14.0, 49.8, 54.0 and $630.0 \mathrm{mg} \mathrm{kg}^{-1}$ respectively.

\section{Soil analysis}

The outcomes of many of basic soil properties table 2, gave hint that texture of soil used in experiment was heavy $(41 \%$ clay), $\mathrm{pH}$ was alkaline 8.1 and non saline the nature EC: $1.6 \mathrm{dS} \mathrm{m}^{-1}$. Consecutively the less soil in OM contented $0.161 \%$ the high extractable K $119 \mathrm{mg} \mathrm{kg}^{-1}$. 
Table 2. Soil properties before experiment

\begin{tabular}{|c|c|}
\hline Soil Property & Values \\
\hline Soil texture & Clayey \\
\hline Ph & 8.1 \\
\hline EC $\left(\mathbf{d S m}^{-1}\right)$ & 1.6 \\
\hline Organic matter $(\%)$ & 0.61 \\
\hline Extractable K $\left(\mathbf{m g ~ k g}^{-1}\right)$ & 119 \\
\hline
\end{tabular}

\section{Agronomic observations}

The maximum plant height of maize was obtained the combine $\mathrm{K}$ nutrients in 300 Kg KEC along with $60(196 \mathrm{~cm}) 45 \mathrm{~kg} \mathrm{~K}$ $\mathrm{ha}^{-1}(183 \mathrm{~cm})$ and $100 \%$, inorganic K (182 $\mathrm{cm}$ ) in respectively figure 1 . These treatments were similar statistically the application of $300 \mathrm{~kg}$ KEC in integrate with 30 and $15 \mathrm{~kg} \mathrm{ha}^{-1}$ lower results in plant height of maize i.e (171 and $165 \mathrm{~cm}$ ) as compared to other integrated $\mathrm{K}$ fertilizer treatments. The lowest plant height was observed when the organic K (KEC @ 300 $\left.\mathrm{KG} \mathrm{ha}^{-1}\right)$ was applied $(160 \mathrm{~cm})$ like the pot field trials also the number of cobs plant ${ }^{-1}$ not changed by the organic $\mathrm{K}$ and combined chemical $\mathrm{K}$ fertilizer and treatments. Where highest 1000 grain maize weight were recorded, for three treatment and statistically as same i.e. were 60 and $45 \mathrm{~kg} \mathrm{ha}^{-1}$ with $300 \mathrm{~kg} \mathrm{KEC} \mathrm{(264} \mathrm{g}$ and $264 \mathrm{~g}$ ) alone inorganic $\mathrm{K} 245 \mathrm{~g}$ while $300 \mathrm{~kg} \mathrm{KEC}$ with integrate 30 and $15 \mathrm{~kg} \mathrm{~K}$ $\mathrm{ha}^{-1}$ the minimum results in 1000 grain weight of maize i.e. $242 \mathrm{~g}, 235 \mathrm{~g}$ and 203 in respectively, The maximum yield of grain maize $\left(6600 \mathrm{~kg} \mathrm{ha}^{-1}\right)$ where the $60 \mathrm{~kg}$ $\mathrm{K}$ with integration of $300 \mathrm{~kg} \mathrm{KEC} \mathrm{ha}^{-1}$ and $\left(5900 \mathrm{~kg} \mathrm{ha}^{-1}\right.$ and $5733 \mathrm{~kg} \mathrm{ha}^{-1} \mathrm{~g}$ ) plant where the maize completely, raising by the supply chemicals and $\mathrm{K}$ fertilizer @ $60 \mathrm{~kg}$ $\mathrm{ha}^{-1}$ the $\left(5600 \mathrm{~kg} \mathrm{ha}{ }^{-1}\right)$ and similarly treatments. However, the yield of grain was noted $300 \mathrm{Kg} \mathrm{KEC} \mathrm{ha-1} \mathrm{was} \mathrm{applied,}$ without any $\mathrm{K}$ fertilizer (3933 $\left.\mathrm{kg} \mathrm{ha}^{-1}\right)$. Maximum stover yield $\left(8033 \mathrm{~kg} \mathrm{ha}^{-1}\right.$ where 60 the $300 \mathrm{~kg} \mathrm{KEC} \mathrm{ha}^{-1}$ and followed the treatment and where $45 \mathrm{~kg} \mathrm{~K} 300 \mathrm{~kg}$ KEC $\mathrm{ha}^{-1}$ applied (7467 $\left.\mathrm{kg} \mathrm{ha}^{-1}\right)$ the maize received $60 \mathrm{~kg} \mathrm{~K} \mathrm{ha}^{-1}\left(6933 \mathrm{~kg} \mathrm{ha}^{-1}\right)$ the lowest stover was recorded the yield of maize $300 \mathrm{~kg}$ KEC integrate with $30 \mathrm{~kg} \mathrm{~K}$ $\mathrm{ha}^{-1}$ and $\left(6800 \mathrm{~kg} \mathrm{ha}^{-1}\right)$ the obtained supplied of maize with $\mathrm{kg}$ KEC $\mathrm{ha}^{-1}$ Minimum stover yield $\left(5167 \mathrm{~kg} \mathrm{ha}^{-1}\right.$ with no inorganic $\mathrm{K}$ fertilizer figure 1 . The greater $\mathrm{K}$ concentration of the maize stover (4.92\%) noted as $60 \mathrm{~kg} \mathrm{~K}$ the $300 \mathrm{~kg} \mathrm{KEC}$ $\mathrm{ha}^{-1}$ as followed by $60 \mathrm{~kg}$ KEC ha ${ }^{-1} \mathrm{~K}$ $(3.81 \%)$ and $(3.80 \%)$ where the $60 \mathrm{Kg} \mathrm{ha}^{-1}$ supply the without any organic $\mathrm{K}$ fertilizer. The lowest $\mathrm{K}$ concentration $(3.25 \%)$ was noticed in treatment having only inorganic $\mathrm{K}$ figure 2 . The greatest concentration of $\mathrm{K}$ in maize grain $(2.67 \%$ and $2.31 \%)$ was found where maize received $300 \mathrm{~kg}$ KEC along 60 and $45 \mathrm{~kg} \mathrm{~K} \mathrm{ha}^{-1}$ respectively. The rest of treatments were statistically similar and $\mathrm{K}$ concentration in grain was ranged between 1.69-1.86\%.

\section{Discussion}

Plenty of analytical work has been done by using different compost of materials to evaluate theirs, impact in enhancing growth and yield of many crops [23], including alfalfa [24], brassica [25], corn [26], rice [27], and tomato [28], in different areas of the globe. The changes in different parameters and quality of soil or nutrient uptake crops in different kinds of compost have been discussed [29, 30]. Many above raise the contain the different tons of compost on a single hectare of the land which is not suitable of this reasons, such as availability and economics. In spite of the fact that materials can be both improve the quality and an appropriate levels these decrease their rate of application and after blending elements $(\mathrm{N}$ $\mathrm{P} \mathrm{K}$ etc .) the soil has given better results [31], the added nutrients these value enriched the compost to prove and useful. 


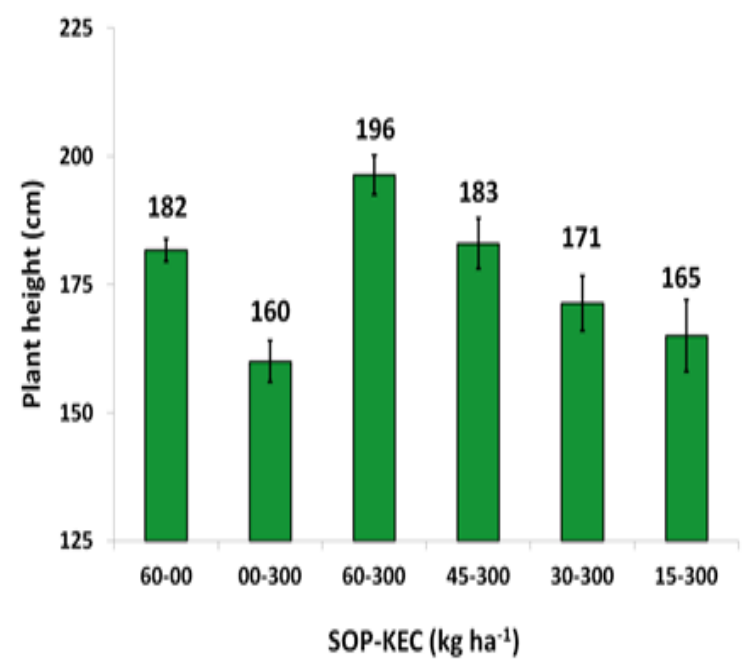

1a. Plant height

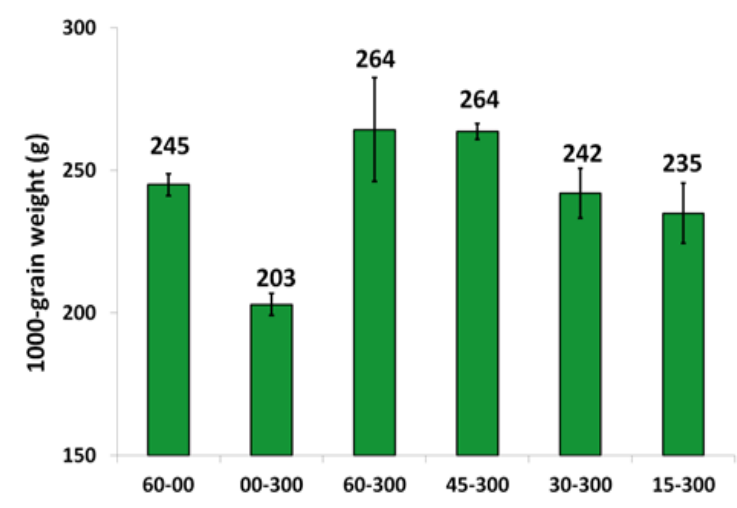

1c. 1000 grain weight

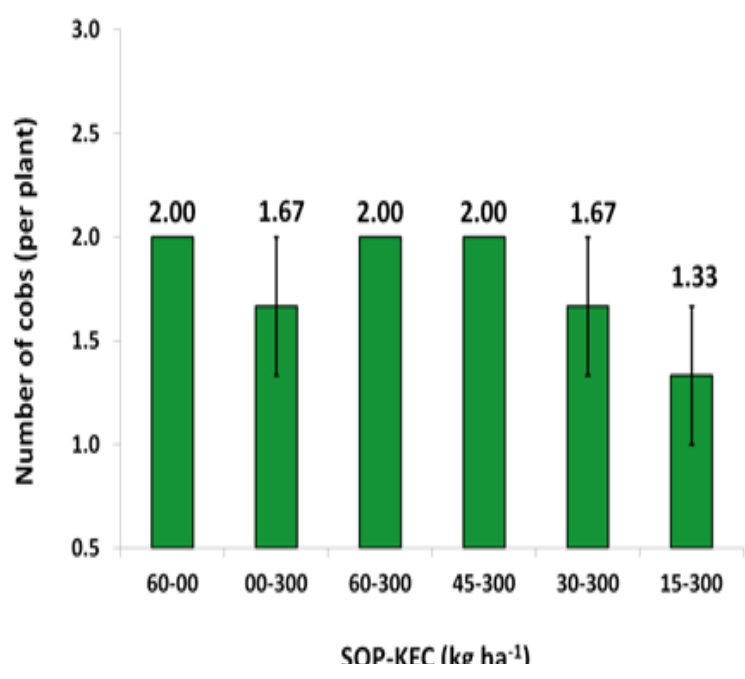

1b. Number of cobs

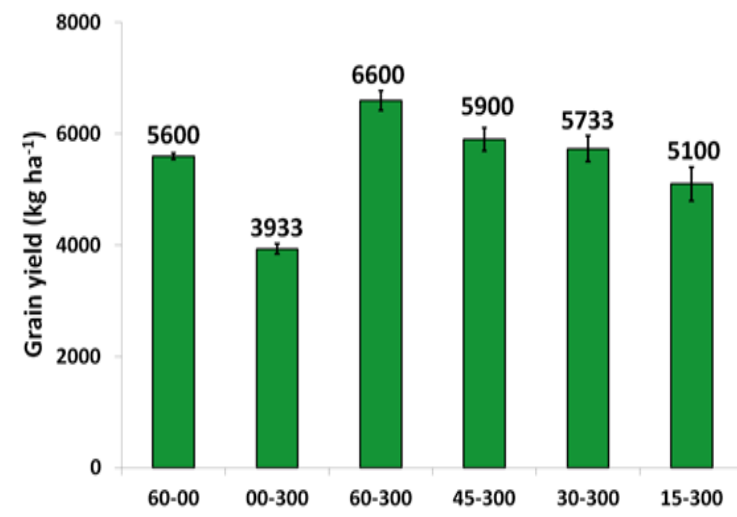

1d. Grain yield

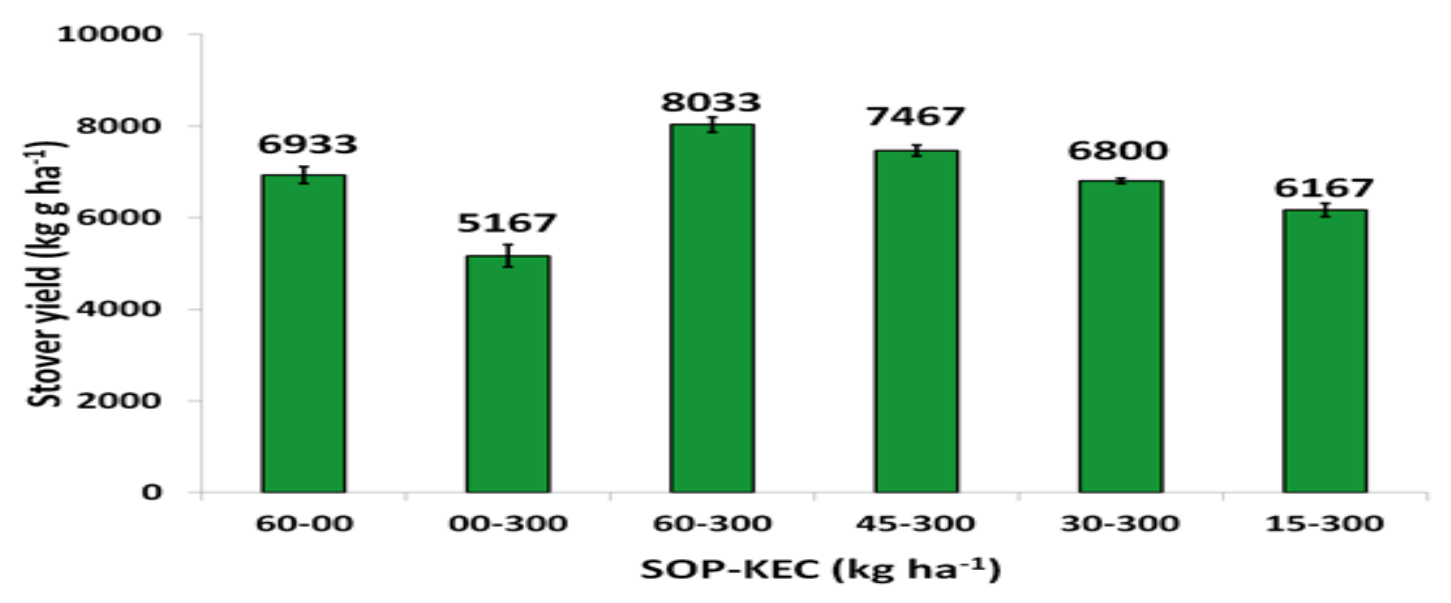

1e. Yield

Figure 1. Effect of potassium enriched compost in integration with inorganic potassium fertilizer on plant height of maize $\left(\right.$ HSD $_{0.05}$ : plant height18.19**, HSD 0.05 : number of cobs $0.99^{\mathrm{NS}}$, HSD 0.05 : 1000-grain weight $41.15^{* *}$, HSD 0.05 : grain yield 729*, HSD 0.05 : stover yield $2895^{\mathrm{NS}}$ ) 


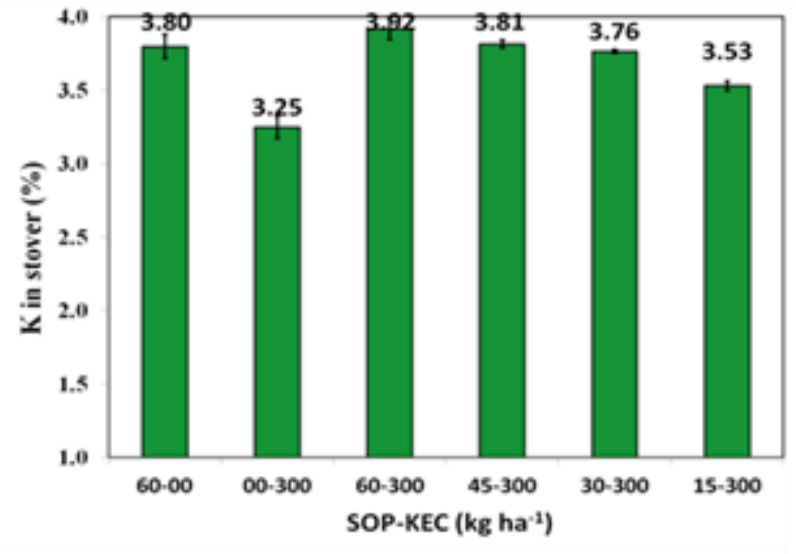

2a. $\mathrm{K}$ in Stover

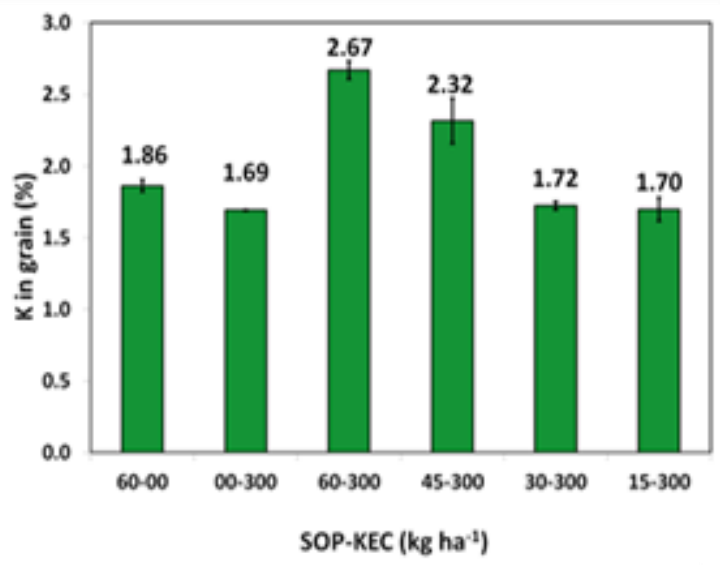

2b. $\mathrm{K}$ in grain

Figure 2. Effect of potassium enriched compost in integration with inorganic potassium fertilizer on $\mathrm{K}$ concentration in stover of maize $\left(\mathrm{HSD}_{0.05}: \mathrm{K}\right.$ in straw $0.31^{* * *}$, $\mathrm{K}$ in grain $0.36^{\mathrm{k}}$ )

The laboratory conducted research data hint that un-decomposed and composted material (KEC) with or without ACCdeaminase rhizobacterial biofertilizers and produced the significant better came for enhancing the quality of compost. The compost of materials and not only decrease the $\mathrm{C}$ to $\mathrm{N}$ ratio of soil as consequence, the nutrients status of soils. The totally stable and decrease water loss from the soil and these outcomes are comparable to previous findings emphasizing the advantage of the materials their organic (raw) and organic materials [32, 33], the enrichments of organic nutrients and materials with has further, utilization when they are applied the form of composed or in un-composed materials. in some early studies, Nenriched the compost NEC were proved to be the beneficial for crops due to their lowest $\mathrm{C}$ to $\mathrm{N}, \mathrm{C}$ to $\mathrm{P}$ and $\mathrm{C}$ to $\mathrm{K}$ ratio and increased the content of nutrients raw materials [34]. The impact $\mathrm{N}$ enriched compost materials as soil conditions have been tested in control environments [35]. The soil and NEC as ACC deaminase contain biofertilizers the greatest amount of soil and aggregate (up to 30\%) remaining in $1.0 \mathrm{~mm}$ sieve. In this experiment it was recorded that the yield and growth contributing traits including, $\mathrm{K}$ concentration of stover and grain of maize as integration application of 60 or $45 \mathrm{~kg}$ $\mathrm{K}+300 \mathrm{~kg} \mathrm{KEC} \mathrm{ha}{ }^{-1}$ as compared to $60 \mathrm{~kg}$ $\mathrm{K} \mathrm{ha}^{-1}$ sole. The subsequent studies and involved in $45 \mathrm{~kg} \mathrm{~K}$ along with the $300 \mathrm{~kg}$ $\mathrm{KEC} \mathrm{ha}{ }^{-1}$ as the best selected dose in this study.

The findings of this study are corroborated with [36], who emphasized the usage of $\mathrm{K}$ for the yield and quality improvement of the maize crop. Likewise, outcomes of other studies revealed that potassium application also promotes leaf area plant height, growth rate, cob length, grain yield and 1000-grain weight which used as a tool for measuring production of maize. In another study, it is reported that all right good, application $\mathrm{K}$ fertilizer improved the maize and quality oil content and crude protein and starch $[37,38]$, reported that the use of organic wastes and materials in raw-unrecompensed from is difficultly to bring use as soil amendment duet to the involvement of cost transpiration and storage [39]. The $50 \%$ of $\mathrm{N}$ fertilizer can be saved if augmented with organic or biofertilizers affecting the production of tomato. They further, reported that the value shown in bracket in comparison the root length (91\%) respectively, were significant the greatest than recommended 
$\mathrm{N}$ fertilizer treatment in (control). The nutrient concentration and utilization by plant were both increase by the usage of these enriched and composts. The discussion of this studies not only confirm the merits of application of organic fertilizer the reported from market waste fruit and vegetable but also urges the soil fertility, and plant nutrients experts to explore further, strategies of formulation of organic fertilizer of low input sustainable crop production.

\section{Conclusion}

The results showed that mixing KEC with the organic K fertilizer @ 60 or 45 kg K ha $^{-1}$ more suggested statistically the similar yield of maize, as the against the recommended does, $60 \mathrm{~kg} \mathrm{~K} \mathrm{ha}{ }^{-1}$ alone. Therefore in the future studies a dose of 45 $\mathrm{kg} \mathrm{K}$ integrate with $300 \mathrm{~kg} \mathrm{KEC} \mathrm{ha}{ }^{-1}$ and found better other treatments to input of the chemical $\mathrm{K}$ fertilizer. Furthermore, the data of this study not only reveals the application of fertilizer and prepared market wastes (Fruits and vegetable) the soil fertility and nutrients of plant experts to explore the further strategies of the formation of organic fertilizer and plant nutrients for sustainable production of crops with low-inputs specially for enhancing the $\mathrm{K}$ fertilizer use efficiency.

\section{Author's contributions}

Conceived and designed the experiments: AN Shah \& MN Kandhro. Performed the experiments: Q Jogi \& ZH Shah. Analysis the data: AN Shah \& GM Jamro. Contributed reagents/ materials/ analysis tools: AN Shah \& MN Kandhro. Wrote the paper: AN Shah.

\section{Reference}

1. Bukhsh MA, Ahmad RJ, Iqbal MM, Maqbool A, Ali M Ishaque \& Hussain S (2012). Nutritional and Physiological Significance of Potassium Application in Maize Hybrid Crop Production. Pak J of Nutri 11(2): 187-202.

2. Cakmak I (2005). The role of potassium in alleviating detrimental effects of abiotic stresses in plants. $J$ of Plant Nutri \& Soil Sci 168: 521-530.
3. Ahmad R, Jilani G, Arshad M, Zahir ZA \& Khalid A (2007). Bioconversion of organic wastes for their recycling in agriculture: An overview of pers \& pros. Annals of Micro 57(4): 471-479.

4. Arshad M, Zia-ul-hassan, Shaharoona B \& Ahmad R (2007). Organic waste management: Bioconversion into value-added soil amendment for sustainable agriculture. ESDev-2007 CIIT Abbottabad, Pakistan, pp 905912.

5. GoP (2017). Economic Survey of Pakistan, 2015-2016. Govt. of Pakistan, Finance Division, Economic Advisor wing, Islamabad, Pakistan.

6. Christensen BT \& Johnston AE (1997). Soil organic matter and soil quality-Lessons learned from longterm experiments at Askov and Rothamsted. Develop in Soil Sci 25: 399-430.

7. Asghar HN, Isha M, Zahir ZA, Khalid A \& Arshad M (2006). Response of radish to integrated use of nitrogen fertilizer and recycled organic waste. Pak J of Bot 38: 691-700.

8. Haug RT (1993). The practical handbook of compost engineering. $2^{\text {nd }}$ edn. Lewis Publishers, Boca Raton, FL.

9. Jamro GM, Chang SX \& Naeth MA (2014). Organic capping type affected nitrogen availability and associated enzyme activities in reconstructed oil sands soils in Alberta, Canada. $J$ of Ecol Engin 73: 92-101.

10. Ahmad N \& Rashid M (2003). Fertilizers and Their Use in Pakistan. Extension Bulletin. Joint FAO-NFDC Publication, Islambad, pp 245.

11. Lynch DH, Voroney RP \& Warman PR (2005). Soil physical properties and organic matter fractions under forages receiving composts, manure or fertilizer. Compost Science and Utilization, Intern J of Sci, 13 (4): 252261. 
12. Erhart E, Hartl W \& Putz B (2005). Biowaste compost affects yield, nitrogen supply during the vegetation period and crop quality of agricultural crops. European J of Agro 23: 305314.

13. Mastoi GS, Zia-ul-hassan, Rajpar I, Shah AN \& Qureshi SA (2013). Response of field grown hybrid maize to integrated use of inorganic and organic potassium fertilizers. Pakistan J of Agri, Agri Engi \& Veter Sci 29 (2): 126-136.

14. Akhtar ME, Saleem MT \& Stauffer MT (2003). Potassium in Pakistan Agriculture. Pakistan Agri Res Council, Islamabad. pp 80.

15. Bhattacharyya P, Chakrabarti K, Chakraborty A, Nayak DC, Tripathy S \& Powell MA (2007). Municipal waste compost as an alternative to cattle manure for supplying potassium to lowland rice. Chemosphere 66: 1789-1793.

16. Ahmad R, Arshad M, Khalid A \& Zahir ZA (2008). Effectiveness of organic-/bio-fertilizer supplemented with chemical fertilizers for improving soil water retention, aggregate stability, growth and nutrients uptake of maize (Zea mays L.). J of Sus Agri 31: 57-77.

17. Ali TS, Anwar WAS \& Ahmad B (2004). Response of maize hybrids/cultivars to various levels of potassium and irrigation frequencies. $J$ of Agro 3: 201-207.

18. Hoeft RG (2007). Maize (Zea mays L.). In: World Fertilizer Use Manual. Intern Ferti Indu Assoc 6: 432-246.

19. Arshad M, Khalid A, Mahmood MH \& Zahir ZA (2004). Potential of nitrogen and L-tryptophan enriched compost for enhancing the growth and yield of hybrid maize. Pak J of Agri Sci 41: 1624.

20. Karlen DL, Flannery RL \& Sadler EJ (1988). Aerial accumulation and partitioning of nutrients by corn. $J$ of Inter Agro 80: 232-242.
21. Rengel Z \& Damon PM (2008). Crops and genotypes differ in efficiency of potassium uptake and use. Physiologia Plantarum 133: 624-636,

22. Karungi JS, Kyamanywa \& Ekbom B (2006). Comparison of the effect of market crop wastes and chemical soil fertility amendments on insect pests, natural enemies and yield of Brassica oleracea. Annual and Appl Bio 149: 103-109

23. Kubar S, Zia-ul-hassan, Sha AN, Rajpar I \& Qureshi AS (2013). Response to a novel organic potassium fertilizer developed from fruit and vegetables wastes. Pakistan J of Agri, Agri Engi \& Vete Sci 29(1): 1-12

24. Usherwood NR (1985). The role of potassium in crop quality. In: Munson RD (Ed). Potassium in Agriculture. Intern J of bio Sci 34: 445-375.

25. Mahmood, Saeed $\mathrm{T} \&$ Ahmad $\mathrm{R}$ (2000). Impact of water and potassium management on yield and quality of maize. Pak J of Bio Sci 3: 531-533.

26. Nawaz MU, Chattha MB, Chattha R, Ahmad HM, Usman M, Hassan MU, Khan S \& Kharal M (2017). Assessment of compost as nutrient supplement for spring planted sugarcane (Saccharum officinarum L.). The J of Animal \& Plant Sci 27(1): 283-293.

27. Zia-ul-hassan, Memon KS, Memon M \& Arshad M (2008). Quantifying the effect of temperature on ammonium bicarbonate diethylenetriaminepentaacetic acid extractable potassium and developing a novel correction factor to express the data. Communications in Soil Sci and Plant Analy 39: 30473056.

28. Tahir M, Arshad M, Naveed M, Zahir ZA, Shaharoona B \& Ahmad R (2006). Enrichment of recycled organic waste with $\mathrm{N}$ fertilizer and PGPR containing ACC-deaminase for improving growth and yield of tomato. $J$ of Soil and Env 25: 105-112. 
29. Statistix (2006). Statistix 8 user guide, version 1.0. Analytical Software, PO Box 12185, Tallahassee FL 32317 USA. Copyright (C) 2006 by Analytical Software.

30. Montemurro FG, Convertini, Ferri D \& Maiorana M (2005). MSW compost application on tomato crops in Mediterranean conditions: Effects on agronomic performance and nitrogen utilization. Compost Sci and Uti 13(4): 234-242.

31. Meille LJ \& Pellerin S (2008). Shoot and root growth of hydroponic maize as influenced by $\mathrm{K}$ deficiency. Plant and Soil 304: 157-168.

32. Pettigrew WT (2008). Potassium influences on yield and quality production for maize, wheat, soybean and cotton. Physiolgia Plantarum 133: 670-681.

33. Nawaz I, Zia-ul-hassan, Ranjha AM \& Arshad M (2006). Exploiting genotypic variation among fifteen maize genotypes of pakistan for potassium uptake and use efficiency in solution culture. PakJ of Bot 38(5): 1689-1696.

34. Ryan J, Estefan G \& Rashid A (2001). Soil and Plant Analysis Laboratory
Manual. $2^{\text {nd }}$ ed. ICARDA. Aleppo, Syria pp $172+$ iii.

35. Shah AN, Tunio SD, Zia-ul-hassan \& Arshad M (2014). Quality assessment of organic andbiofertilizers developed from fruit and vegetable waste. Pak $J$ of Agri, Agri Engi \& Veter Sci 30 (1): 32-42.

36. Wakeel A, Rehman $\mathrm{H}$ \& Hillel $M$ (2017). Potash use for sustainable crop production in Pakistan: A review. International J of Agri \& Bio 19(3): 381-390.

37. Warman PR \& Termeer C (2005). Evaluation of sewage sludge, septic waste and sludge compost applications to corn and forage: yields and N, P and $\mathrm{K}$ content of crops and soils. Bioresource Technology. Intern $J$ of Bio 96: 955-961.

38. Zia-ul-hassan, Arshad M \& Khalid A (2011). Evaluating potassium-useefficient cotton genotypes using different ranking methods. $J$ of Plant Nutri 34: 1957.

39. Martin EC, Slack DC, Tanksley K \& Basso B (2006). Effects of fresh and composted dairy manure applications on alfalfa yield and the environment in Arizona. Inter J of Agro 98: 80-84. 